\title{
D_e_c_l_e_r_e_t_i_on $n$
}

On 13.10.1976, there were published in the Codex of Laws of the CSSR /ne.120 an "Internationel Pact on Civil and Political Rights" and an "International Pact on Economic, Social and Culturel Rights", which had been signed on behalf of Czechoslovakia in 1968, confirmed at Helsinki in 1975 and which came into force in our country on 23.3.1976. Since that time our citizens have had the right and our state the duty to be guided by theal

The freedons end rights of the people guaranteed by these pacts are important factors of civilization for which, throughout history, any progressive force: have been striving and their enactiment cen be of great assistance to the humanistic development of our society. We therefore welcome the fact that the Czechoslevak Socialist Republic has expressed acherence to these pacts.

But their publication remirds us with new urgency how many fundemental civi] rights for the time being are - unhappily - valid in our country only on paper. Completely illusory, for example, is the right to freedom of expression, gueranteed by article 19 of the first pact.

Tens of thousands of citizens are not allowed to work in their own branches simply because they hold opinions which differ from official opinions. At the same time they are erequently the object of the most varied forms of diecriminetion and persecution on the part of the authorities and social organizations; they are deprived of any possibility of defending themselves and are virtually becoming the victioms of apartheid.

Hundreds of thousands of other citizens are denied the right to "freedom Mam from fear" /preamble of the first pact/, because they are forced to live in constant danger that if they express their opinions they will lose their possibility to work and other possibilities.

In contradiction to article 13 of the second pact, guaranteeing to all the right to education, there are countless young people who are prevented frol studying because of their opinions or even those of their parents. There are citizens without number who must live in the fear that if they expreas themselves according to their convictions, they themselves or their children would be deprived of the right to education.

The implementation of the right "to seek, receive and spread information and ideas of all kinds, regardless of frontiers, either orally, in writing or in print, or by means of art" /pt.2, art.13 of the first pact/ is subject to persecution, not only outside the courts but judicially too, often under the guise of criminel charges /as is borne out, among others, by the trials of young musicians now going on/.

Freedos of public expression is suppressed by the central direction of all informetion medis anc publishing and cultural activities. No political, philosophicel or scientific opinions or artistic expression, differing in the sligh. test degree from the narrow framework of official ideology or aesthetics, can be published; public criticism of sociel phenomeno of the erisis is wade 
imposible; publicly defending oneself against the untrue and insulting charges of official propaganda is rendered impossible,/legal protection against "attacks on honour and reputation" unamiguously guaranteed by article 17 of the first pact is in practice non-existent/; false accusations cannot be challenged and any effort to achieve rectification or amendment by judicial means is in vain; in the sphere of spiritusl and cultural creative work frenk discussion is ruled out. Many scientific and cultural workers and bher citizens are diacriminated against just because some years earlier they legally published or openly expressed opinions which are condemed by temporary politicel power.

Freedom of religious conviction, emphatically guaranteed by article 18 of the first pact is systematically restricted by arbitrary power by the curtailment of the activities of the clergy who are constantly under the threat of the withholding or loss of state agreerent with the execution of their office, threats against the weans of existence and other reprisals of those who express their religious beliefs by word or deed, the suppression of the teaching of re. ligion and so on.

What constitutes an instrument for the restriction and often for the conplete suppression of a whole number of civil rights is the systea of the virtual subjection of all institutions and orgenizations in the state to the politicel directives of the apparatus of the ruling party and the arbitrery decisions of the influentiel individurls. The constitution of the CSSR and other laws and legal norms do not define either the content or form the establishment snd application of such decisions; they are mainly exercised behind the scenes, often only verbally, unknown to the citizens of the country and beyond their control; their originators are responsible to no one but thcmselves and theif hierarchy, although they have a decisive influence on the activity of legislative and executive orgens of state administration, justice, trede union and various other social organizations, other political parties, enterprises, factories, institutes, offices, schools and other bodies, while their orders have priority even before the law. Should organizations or citizens in the exercise of their rights and duties come into conflict with a directive, they cannot turn to any impartial institutio because none exists. These are all serious restrictions of the rights arising fron articles 21 and 22 of the first pact / the right to assembly and the banning of any kind of restriction of their exercise/, also article 25 / equel rights to shar on the running of public affairs/ and $36 /$ the elimination of discriminetion before the law/. This state of affairs also prevents workers and other working people from establishing tradeunion or other organizetions and freely using the right to strike /point 1 , article 8 of the second pact/.

Other civil rights, including the express benning of "arbitrary interference in private life, the fonily, home and correspondence" /art.17 of the first pact/, are hazardously violated by the ct, too, that the Ministry of Interier 
by various meens controls the life of citizens, for exemple by the "bugging" of telephones and flats, control of posts, a watch on persons, the searching of homes, the creation of a network of informers from the ranks of the population /often recruited by impermissible threats or, on the contary, promises/ etc. Often it intervenes in the decision-making of employers, insperes discriminatory cempaigns on the part of offices and organizations, influences organs of the judiciary and direct propagand campigns of the information media. This activity is not regulated by laws, it is carried out secretly and citizens have no defence against it.

In cases of politically motivated criminal proceedings, the investigating organs violate the rights of the accused anc their cefence counsels, guaranteed by article 14 of the first pact and by Czechoslovak legielation. In prisons persons thus sentenced are treated in a manner violating human dignity, their health is endangered and attempts are made to destroy them morally.

Also generally contravebed is point 2 of article 12 of the first pact which guarantees citizens the right to leave their country freely, under the pretext of "protecting national security /pt.4/, this right is bound up with various impermisaible conditions. There is an arbitraby approach, too, in the granting of entry visas to subjects of states, any of whon may not visit Czechoslovakia because, for example, they may have had working or friendly contact with persons who are discriminated against in our country.

Some citizens - either privately, at their places of werk or publicly this latter being virtually possible only in foreign information media call attention to the systematic violation of human rights and democratic freecoms and, in concrete cases, demend rectification. But in the jority of cases there is no response to their appeals or they themselves are subjected to investigation.

Responsibility for the observance of eivil rights in the country naturally folls, in the first place, on the political and state power. But not on it alone. Each and every one of us has a share of responsibility for the general situation and thus, too, for the observence of the pacts which have been enacted and are binding not only for the gevernment but for all citizens.

The feeling of co-respensibility, faith in the idea of civic involverent and the will to exercise it and the common need to seek new and more effective meane for it expression led us to the idea of setting up CHAR TER ' 77 , the origin of which we are publicly announcing today.

CHARTER 77 is a free, informel and open associalion of people of different convictions, different faiths and different professions, whe are linked by the desire, indivioually or jointly, to insist on the respecting of civil and humin rights in our country and throughout the world, rights recognised for man both by the enacted internetionel facts, the Finel Act of the Helsinki Conference and wony other internationsl documento ageinst wars, violence and sociel and spirituel oppression and which are expressed as a whole in the United Nations Declaration of Hunen Rights. 
CHARTER 77 arose from the background of the solidarity and friendiship of people who share concern for the fate of the ideals to which they have linked their life and work.

CHARTER 77 is not an organization, it has no statutes, no parmanent mggnm organs and no organised membership. Everyone whe agrees with the idea b hind it, participates in its work and supports it is its member.

CHARTER 77 is not a base for oppositions political activity. It wants to serve the generel interest like many similar examples of civic iniciative in various countries - West and East. It does not want to lay down its wan own programes of political or social reforms or changes but to engage in the spheres of its activity in a constructive dialogue with political and state power, especially by calling attention to various concrete instances of the violetion of humen and civil rights, to prepare documentation on them, propose selutions, subvit verious general proposels aimed at deepening these rights and gurranteeing them and to act as intermediary in cases of conflicting situations which can evoke wrongful action, etc。

By its symbolic name, CHARTER 77 emphasises that it is coming into being on the threshold of the year which has been declared the year of the rights of political prisoners and in which the Belgrade Conference is to check up on the fulfilment of the pledges undertaken at Helsinki.

As signateries of this declaration we have entrusted Prof.Dr. Jiri Hájek DrSc., Václav Havel and Prof.Dr.Jan Patocka DrSc.h.c., with the role of spokesmen of CHARTER '77. These spokesmen have full power to represent it before the state and ther organizations abd before our people and the world public and to guarantee by their signatures the authenticity of its documents. We and other citizens who join us will be their fellow-workers who will take port with them in necessary negotiations, undertake partials Man tasks and will share with them all responsibility.

We believe that CHARTER 77 will contribute towards all citizens in Czechoslovakia working and living as free people.

1.1 .1977 


$$
\underline{O} B, A \quad I \quad \mathbb{K} \quad A
$$

s listinnju doličnýn matexálem, letcmý byl odnat dne 7.lecina 1977 pěovédëné domovaí prohlídce u:

PETRGMKK Jan, byten Praha 3, Jičínská ul.,ě..35

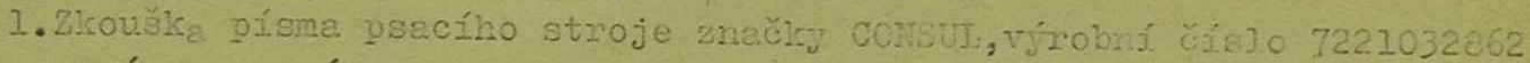

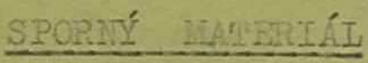

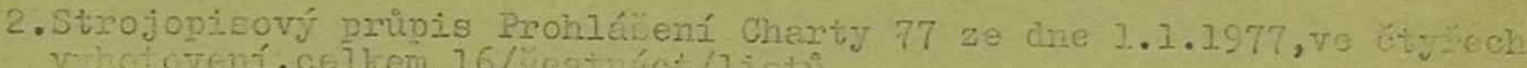

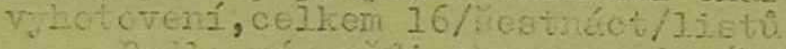

Polih che obcržel pruipis Chaxty 77 od Jirího HiJKA a na vlestním psacím stroji a pro svou potịebu prý, uvedenou Charu 77 asi $4 x$ nebo $5 x$ rozimozil por. Ćs. protolkolu o provedení. DP I

3. Strojopisový pmipis s n zVen DECLiR, IOII of CHA IIIR 77,ze dine 1.1.1977, ve trojím vyhotovení, celken 12/avenáct/1istul/

Podle výpovedi shora uvedeného si provedl s pirvodní Charty kterou obdriel preilad do angličtiny a na vlasinín pacán stroji do englictiny prepsel.

Doo . óśs. protokolu o oxovedení DP 2

4. VOTMA PR̃́fIOHA

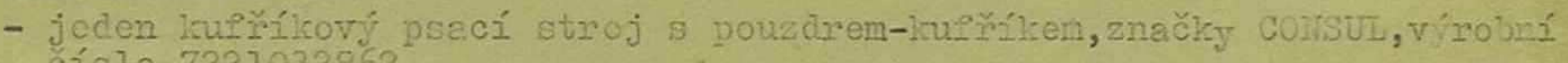
císlo 7221032862 